\title{
Product development drivers in literature and practice
}

\section{Jukka Majava*, Harri Haapasalo, Pekka Belt and Matti Mottonen}

Department of Industrial Engineering and Management, University of Oulu, P.O. Box 4610, FI-90014, Finland

E-mail: jukka.majava@oulu.fi

E-mail: harri.haapasalo@oulu.fi

E-mail: pekka.belt@oulu.fi

E-mail: matti.mottonen@oulu.fi

*Corresponding author

\begin{abstract}
Today's product development must address often conflicting needs of multiple stakeholder groups. The purpose of this paper is to clarify the main product development drivers and how their importance is perceived in different types of companies and projects. This paper presents a synthesising list of main product development drivers based on literature, and studies how these drivers are valued at the managerial level in NPD-intensive companies. The literature tends to give a simplified categorisation for product development drivers to fully acknowledge the complexities that product development managers face. The results of this study indicate 18 significant product development drivers, the most important ones being profitability targets, revenue targets, offering the right product mix, company brand and image, strategy, and competition. However, there were big differences in driver importance for different project types and companies. Industrial managers can utilise the findings in clarifying their drivers to improve decision-making and reduce unnecessary ambiguities.
\end{abstract}

Keywords: Product development; NPD; product development driver; stakeholder needs; project type.

Biographical notes: Jukka Majava received his M.Sc. in Engineering from the University of Oulu, Finland, in 1999. His industrial experience includes technology marketing, customer care, partner management, project management, and supply chain development at Nokia Corporation. Currently he works as a Doctoral Student in the Department of Industrial Engineering and Management at the University of Oulu.

Dr. Harri Haapasalo is Dean for Research, Faculty of Technology, and Professor of Technology Management in the Department of Industrial Engineering and Management at the University of Oulu. He has a PhD in Technology Management and a Master's degree in Economics and Business Administration, both from the University of Oulu, Finland. He has research interests in planning, product development, and technology commercialisation.

Dr. Pekka Belt received his M.Sc. in Engineering in 1984 and his Dr (Tech) in 2009, 


\begin{abstract}
Author
both from the University of Oulu, Finland. He has extensive industrial experience at managerial level from several electronics enterprises, covering company functions from technology development to international marketing. Dr. Belt's research interests include entrepreneurship, entrepreneurship education, product development and international marketing. He has authored and co-authored some thirty journal articles, and also a number of other publications.

Dr. Matti Mottonen received his M.Sc. in Engineering in 2006 and his Dr (Tech) in 2009, both from the University of Oulu, Finland. His research interests cover product development, requirements management, and high-tech internationalisation. He has authored and co-authored some twenty journal articles, and also a number of other publications.
\end{abstract}

\title{
1 Introduction
}

Innovation is vital to sustain and advance companies' current businesses and to create new ones (Chesbrough, 2003). Over the years, many authors including Schumpeter (1939), Prahalad and Hamel (1990), and Pavitt (1990) have contributed to the innovation and product development debate. Cooper (2011) argues that new products improve revenues, market shares, net results, and share prices. However, despite this significance, most product development projects fail (Berggren and Nacher 2001; Boulding, Morgan, and Staelin, 1997). New products vary from new-to-the-world to minor revisions of existing products (Kotler and Keller, 2009), and many product development types exist, such as research and development (R\&D), breakthrough, platform, and derivative projects (Schilling and Hill, 1998). Product development has also been studied from various perspectives including product development decisions; see for instance a review article by Krishnan and Ulrich (2001).

Product development is not only a design, marketing, or manufacturing problem. It is a cross-functional effort, and almost all company functions participate in it. In addition, product development is not just an intra-firm activity. Narver and Slater (1990) argue that market orientation consists of customer orientation, competitor orientation, and inter-functional coordination. There are also various stakeholder needs that must be taken into account in product and process design by using integrated methods such as DfX (Bralla, 1996; Mottonen et al., 2009) and concurrent engineering (Krishnan, Eppinger, and Whitney, 1997). Furthermore, today's products can be complex combinations of tangible and intangible components, which are created in development networks in different geographical locations (van Echtelt et al., 2008). However, overly bureaucratic NPD processes should be avoided.

The original motives for starting a product development project affect decision-making and the outcome of development in companies. Cooper (2011) lists four drivers for new product development (NPD): technology advances, changing customer needs, shortening product life cycles, and increased globalisation. Literature related to product development drivers includes, for example, strategy typology by Ansoff (1957) and debate on technology-push vs. marketpull (Isoherranen and Kess, 2011; Rothwell, 1992). In addition, drivers for radical products (Veryzer, 1998), drivers for creativity in product development (Lakemond, Lovén, and Detterfelt, 2010), and NPD and innovation drivers in specific business sectors have been explored (Bossink, 2004; Hassanien and Dale, 2012; Kinkel and Som, 2010). The literature tends to give a simplified categorisation for product development drivers to fully acknowledge 
Title

the complexities that product development managers face. In addition, the literature has not adequately covered drivers for different types of projects.

This study reviews the earlier research on product development drivers and proposes a list synthesising the main drivers. In addition, this paper studies how the drivers are perceived at the managerial level in NPD-intensive companies. The study also covers how drivers are valued in different project types and in different types of companies. Accordingly, this paper addresses the following research questions:

1. What are the main product development drivers in literature?

2. How do managers in industrial companies value these different drivers?

\section{Literature review}

\subsection{Product development and innovation}

Product development activities can be seen as part of innovation management. Product development transforms market opportunities into production, sale, and delivery of product. The product can be completely or partially new (Krishnan and Ulrich, 2001; Ulrich and Eppinger, 2000). Innovation management aims to create the necessary conditions for innovations to occur (Trott, 2002). Innovation is not just new idea, invention, new technology, or market development; it is management of all activities involved in creating new or improved products or processes (Myers and Marquis, 1969; Trott, 2002).

New products can be divided into categories such as new-to-the-world products, new product lines, additions to existing product lines, improvements and revisions of existing products, repositionings, cost reductions, market pull, technology push, platform products, process intensive, and customised products (Booz, Allen, and Hamilton, 1982; Cooper, 2004; Ulrich and Eppinger, 2000). Most new products are not completely new, but merely imitations that differ from the existing products only a little (Ettlie, 2006; Trott, 2002).

Product development projects can also be classified in various ways, such as pure R\&D, breakthrough (Schilling and Hill, 1998), platform, and derivative projects (Schilling and Hill, 1998; Ulrich and Eppinger, 2000), incremental improvements, and fundamentally new products (Ulrich and Eppinger, 2000). In service development two extremes are incremental innovation and radical innovation (Ettlie, 2006). Most established companies focus on incremental innovations, which enable them to enter new markets with product modifications (Kotler and Keller, 2009).

\subsection{Product development drivers}

Strategy is one of the main drivers for product development (Acur, Kandemir, and Boer, 2012; Ansoff, 1957; Kahn, 2001; Trott, 2002). Strategic planning involves, for example, assessing technologies and markets and examining the fit between intended new products and a company's strategy (Acur, Kandemir, and Boer, 2012). Product strategy can be seen as the foundation of development initiatives (Ansoff, 1957). New product strategy is linked to and derived from other strategies such as corporate, marketing, and technology strategy (Trott, 2002), and is implemented via product development programmes (Kahn, 2001).

New products can positively impact revenues (Cooper, 2011; Hassanien and Dale, 2012; Lantos, Brady, and Mccaskey, 2009), share prices (Cooper, 2011; Lantos, Brady, and 


\section{Author}

Mccaskey, 2009), market shares, and net results (Cooper, 2011; Kahn, 2011). There are also various marketing-related factors that stimulate NPD, including the need to enhance image and awareness (Kahn, 2001; Lantos, Brady, and Mccaskey, 2009), leverage brand equity, offer an appropriate product mix, and capitalise on brand halo effects (Lantos, Brady, and Mccaskey, 2009).

Product development drivers in external environment include competitive environment (Hassanien and Dale, 2012; Kahn, 2001) and shorter product life cycles (Cooper, 2011; Hamm, 2006; Lantos, Brady, and Mccaskey, 2009). New trends, such as sustainability and globalisation, affect product development (Cooper, 2011; Hassanien and Dale, 2012; Nidumolu, Prahalad, and Rangaswami, 2009). The external environment also includes constraints and opportunities related to, for example, technology, legislation (Trott, 2002), and new regulations (Kahn, 2001).

Customer orientation is an essential part of market orientation (Narver and Slater, 1990). Customer needs and attitudes are changing, and consumers are used to getting new offerings (Cooper, 2011; Kahn, 2001). Customers and their feedback are a source for new opportunities and improvements (Hassanien and Dale, 2012; Trott, 2002). However, close relationships with customers can also restrict a company in responding to market changes (Sull, 1999). Therefore, companies also need their own foresight in product development (Hamel and Phalahad, 1994).

Technology-push and market-pull are alternative drivers for product development (Hart et al., 2003; Rothwell, 1992). Market and customer needs are utilised for developing market-pull products, whereas for technology-push products technology is the driving force (Ulrich and Eppinger, 2000). Advances in technology are an important NPD driver, as they enable creation of new products and solutions (Cooper, 2011; Bossink, 2004; Kahn, 2001). Development of really new products is often "probing and learning" (Song and Montoya-Weiss, 1998), and it can also be a way of building new competences in a company (Trott, 2002). New opportunities can also be found from existing products, technology, and unexploited patents (Trott, 2002).

Underused and new resources, such as excess capacity or an acquisition, can provide product development opportunities (Hassanien and Dale, 2012; Kahn, 2001). Vendors, distribution channel members, and partners are also sources for new opportunities or drivers for product modification (Kinkel and Som, 2010; Trott, 2002). In addition, the opportunity and idea sources include existing products, senior and top management, and even individuals (Kahn, 2001; Trott, 2002).

Drivers for different product and project types differ significantly. Key drivers for radical projects include technology convergence, contextual and environmental factors, and individuals with a strong vision, whereas incremental products benefit more from customer input (Veryzer, 1998). Existing production capability is typically utilised in the development of processintensive products, whereas for customised products the driver is typically a response to a customer-specific order (Ulrich and Eppinger, 2000).

Table 1 synthesises the main product development drivers described in literature. 
Title

Table 1. Grouping of product development drivers based on literature review

\begin{tabular}{|c|c|c|}
\hline Category & Drivers & Literature sources \\
\hline Financial goals & $\begin{array}{l}\text { Profitability targets } \\
\text { Revenue targets }\end{array}$ & $\begin{array}{l}\text { Cooper, 2011; Hassanien and Dale, } \\
\text { 2012; Kahn, 2001; Lantos, Brady, and } \\
\text { Mccaskey, } 2009\end{array}$ \\
\hline $\begin{array}{l}\text { Strategy and business } \\
\text { environment }\end{array}$ & $\begin{array}{l}\text { Strategy } \\
\text { Competition } \\
\text { External environment }\end{array}$ & $\begin{array}{l}\text { Acur, Kandemir, and Boer, 2012; } \\
\text { Ansoff, 1957; Cooper, 2011; } \\
\text { Hassanien and Dale, 2012; Kahn, } \\
\text { 2001; Nidumolu, Prahalad, and } \\
\text { Rangaswami, 2009; Trott, 2002; } \\
\text { Veryzer, } 1998\end{array}$ \\
\hline $\begin{array}{l}\text { Marketing and } \\
\text { customers }\end{array}$ & $\begin{array}{l}\text { Company brand and image } \\
\text { Offering the right product mix to } \\
\text { satisfy customers } \\
\text { Customer request, changing needs, } \\
\text { feedback or idea }\end{array}$ & $\begin{array}{l}\text { Cooper, 2011; Kahn, 2001; Lantos, } \\
\text { Brady, and Mccaskey, 2009; } \\
\text { Rothwell, 1992; Trott, 2002; Ulrich } \\
\text { and Eppinger, } 2000\end{array}$ \\
\hline Technology & $\begin{array}{l}\text { New technology is available } \\
\text { Existing technology / new idea based } \\
\text { on existing products }\end{array}$ & $\begin{array}{l}\text { Bossink, 2004; Cooper, 2011; Hart et } \\
\text { al., 2003; Kahn, 2001; Lantos, Brady, } \\
\text { and Mccaskey, 2009; Rothwell, 1992; } \\
\text { Trott, 2002; Ulrich and Eppinger, } \\
\text { 2000; Veryzer } 1998\end{array}$ \\
\hline $\begin{array}{l}\text { Internal push and } \\
\text { resources }\end{array}$ & $\begin{array}{l}\text { Company's own foresight, } \\
\text { management, individuals } \\
\text { Organisational learning } \\
\text { New resources } \\
\text { Underused resources }\end{array}$ & $\begin{array}{l}\text { Hamel and Phalahad, 1994; Hassanien } \\
\text { and Dale, 2012; Kahn, 2001; Trott, } \\
\text { 2002; Veryzer, } 1998\end{array}$ \\
\hline $\begin{array}{l}\text { Supply chain } \\
\text { stakeholders }\end{array}$ & $\begin{array}{l}\text { Production process } \\
\text { Suppliers } \\
\text { Partners } \\
\text { Distributors }\end{array}$ & $\begin{array}{l}\text { Kinkel and Som 2010; Trott, 2002; } \\
\text { Ulrich and Eppinger, } 2000\end{array}$ \\
\hline
\end{tabular}

\section{Research process}

The research process applied in this study is presented in Figure 1. The study started with a literature review on product development drivers and different types of product development projects. The literature review was conducted to form a summarising list for product development drivers from a managerial perspective. Second, the driver list was validated by interviewing two industrial professionals. These two senior experts had versatile experience in different industries, both as product development and product management leaders and entrepreneurs. Third, an empirical survey was planned and the survey questionnaire was 


\section{Author}

created. Fourth, company representatives were invited to participate in the survey to clarify the views on product development drivers at the managerial level. After the survey was conducted, the data was analysed and conclusions were made.

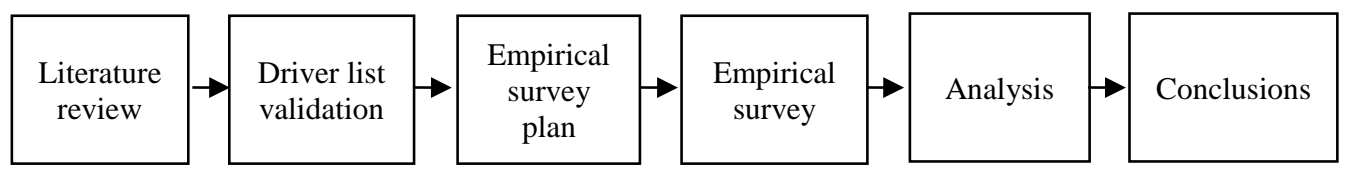

Figure 1. Research process

The empirical data was collected via a web-based survey that was emailed to experienced managers in different types of companies (Table 2). In the survey, the managers were asked to evaluate the importance of product development drivers for three different project types: small change development, typical full-scale development, and radical development. Each driver was evaluated by the experts using the scale not important $=0$, somewhat important $=1$, important $=2$, and very important $=3$. The common characteristics for selected companies are that product development is critical for their business, they serve international markets, and they have influential operations in Finland. The companies were selected so that they would represent many types of product development in business-to-business (B2B) and business-toconsumer (B2C) markets. The products were different types of tangible products, and in many cases they were combined with services and software. The case companies represented different industrial sectors including machinery, ICT, consumer electronics, and consumer goods. 
Title

Table 2. Company characteristics, number of responses, and number of surveys distributed

A

B2B company serving many industries in international markets

Annual revenue over 1 BEUR

Over 10000 employees

B

$$
\text { B2C company serving }
$$
international markets

Annual revenue below 100

MEUR

Hundreds of employees

C

$$
\text { B2C company serving }
$$
international markets

Annual revenue over 10 BEUR

Tens of thousands of employees

D B2B company serving
international markets

Annual revenue over 10 BEUR

Tens of thousands of employees

E

$$
\text { B2C company serving }
$$
international markets

Annual revenue over 100 MEUR

Over one thousand employees

F

B2B company serving many industries in international markets

Annual revenue around 1 BEUR

Over one thousand employees

G
Tangible products with $14 / 18$ services

Tangible products

$6 / 10$

Tangible products, software, and services

Tangible products, software, and services

Tangible products and $7 / 10$ software

Tangible products and $3 / 5$ software platforms

$$
\text { Tangible products } \quad 6 / 10
$$
international markets

Annual revenue over 50 MEUR

Hundreds of employees

The survey respondents were carefully selected in co-operation with the key contact persons in the participating companies to ensure that they had broad knowledge on the topic. Product development is cross-functional in nature; therefore the target group was selected to represent a 


\section{Author}

wide range of company functions including product development, product management, marketing, sales, and operations and logistics. The respondent positions included vice president, director, head, senior manager, manager, programme manager, and project manager. The aim was to achieve a target group with approximately $40 \%$ of respondents from product development, approximately $20 \%$ from product management, and the rest from other functions close to product development.

The survey took place during summer 2012, and a total of 47 responses were received, resulting in a response rate of $62.7 \%$, providing a good basis for analyses. Table 3 presents the distribution of responses in terms of respondent functions and positions. The researchers analysed the responses and the case companies to obtain understanding over the studied issues. Kruskal-Wallis one-way analysis of variance adjusted for ties was used for statistical comparisons between groups.

Table 3. Respondents' functions and positions

Function (responses / surveys distributed)

Position (responses / surveys distributed)

Product development (17/33)

Product management $(12 / 15)$

Marketing (4/5)

Sales $(2 / 4)$

Operations and logistics (5/5)

Other function $(7 / 13)$
Vice president $(7 / 11)$

Director $(16 / 29)$

Senior manager / Head (13/21)

Programme / project manager (8/8)

Other position $(3 / 6)$

\section{Results}

\subsection{Key product development drivers}

Key persons in the case companies were asked to prioritise the product development drivers identified in the literature review. Figure 2 presents the average score for all 18 product development drivers given by all survey respondents. 
Title

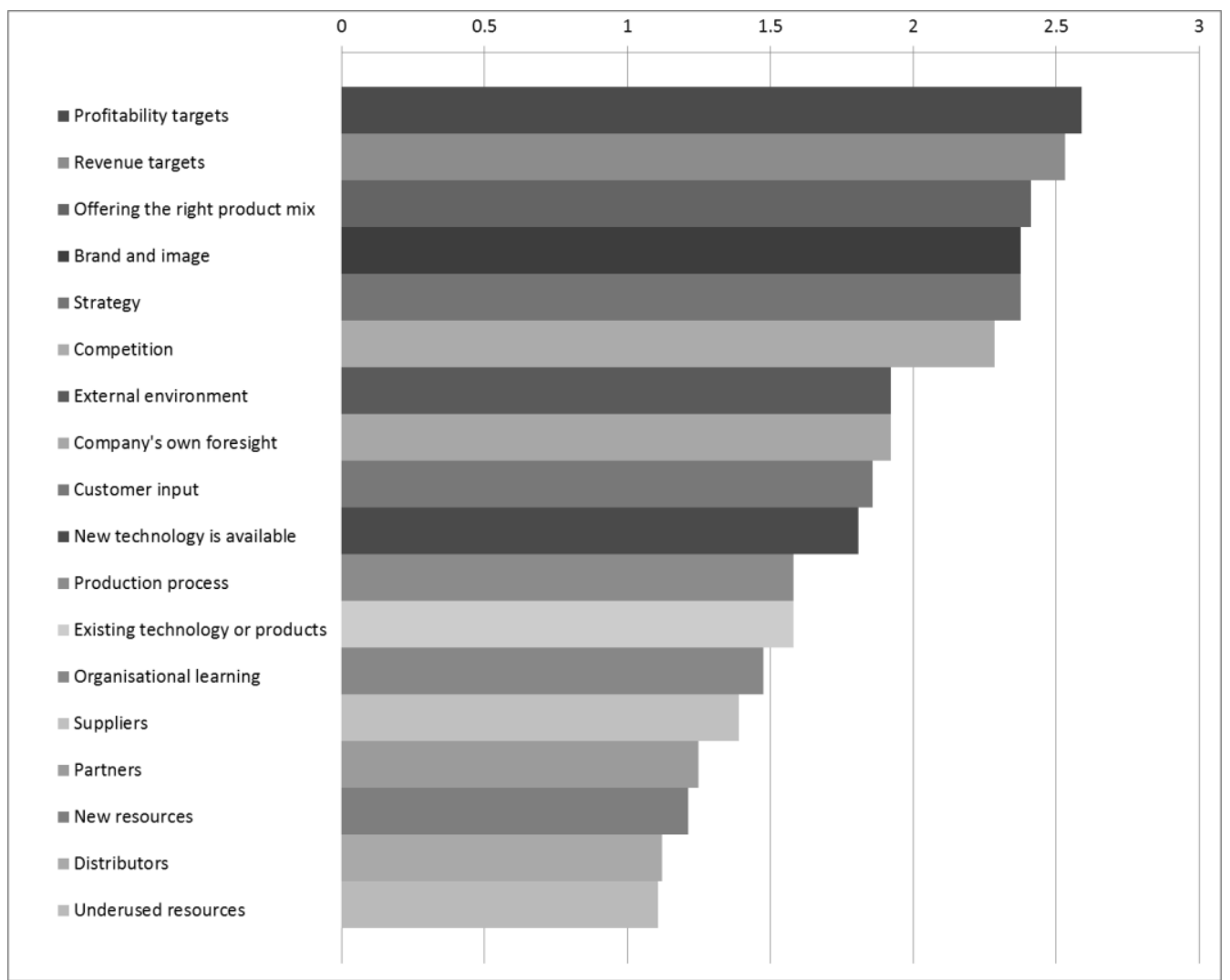

Figure 2. Product development drivers and their importance in the case companies

The distributions of the scores were found to be significantly different between the drivers (Kruskal-Wallis, $\mathrm{N}=2538, \mathrm{P}<0.001$ ). The results indicate that there are six factors that rise above others. The respondents saw financial targets as the most important reason for doing product development. The financial targets cannot be achieved without attractive products, i.e. offering the right product mix to satisfy customers. Company brand and image and strategy were seen as equally important. Increased competition has made product life cycles shorter, and competition was also seen as a key driver for product development.

In addition to the key factors discussed above, another four drivers formed the second important group. These included external environment, company's own foresight, customer input, and new technology. On the other hand, production process, existing technology or new idea based on existing products, organisational learning, and suppliers were only considered somewhat important. Finally, partners, new resources, distributors, and underused resources were considered least important.

The importance of each driver category identified in the literature review was calculated based on the scores of individual drivers. This is illustrated in Figure 3. Statistically significant differences (Kruskal-Wallis, $\mathrm{N}=2538, \mathrm{P}<0.001$ ) were found between the categories. 
Author

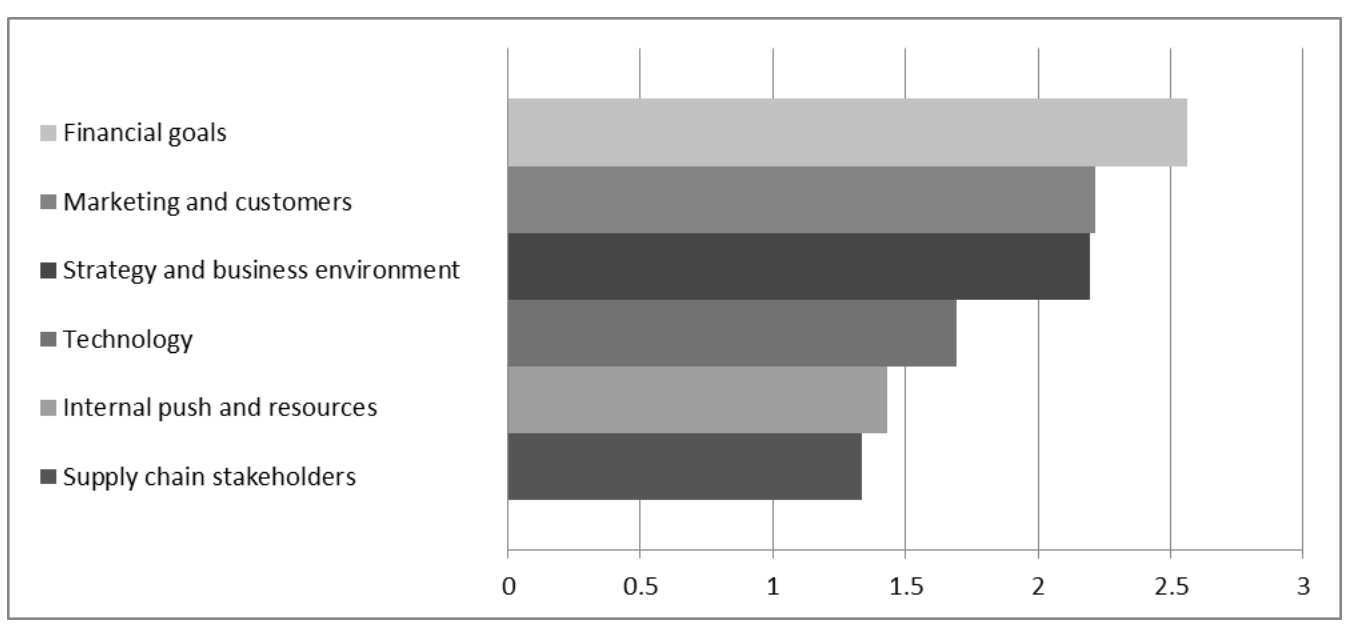

Figure 3. Product development driver categories and their importance

Figure 3 highlights the significance of three driver groups that exceeded score 2, the threshold for important. These groups included financial goals, marketing and customers, and strategy and business environment. Technology proved to be only somewhat important. Internal push and resources and supply chain stakeholders were considered least important.

\subsection{The effect of project type}

The survey results were analysed to clarify the effect of project type on the driver prioritisation. Figure 4 presents the drivers, for each project type, that exceeded 2.25. The appendix provides further details on the scores.

\section{Radical development}

\section{Strategy}

Brand and image

Revenue targets

Profitability targets

Offering the right product mix

Competition

Company's own foresight

New technology

External environment

\section{Typical full-scale development}

Profitability targets

Offering the right product mix

Revenue targets

Strategy

Competition

Brand and image

\section{Small change development}

Profitability targets

Revenue targets

Figure 4. Most important drivers for product development project types

In small change development there were only two drivers that exceeded 2.25: profitability targets and revenue targets. In typical full-scale development the number of drivers exceeding 2.25 grew to six, including profitability targets, offering the right product mix, revenue targets, strategy, competition, and company brand and image. In radical development the list of drivers exceeding 2.25 was even longer, including nine drivers: strategy, company brand and image, 
revenue targets, profitability targets, offering the right product mix, competition, company's own foresight, new technology, and external environment.

In addition to analysing the number of drivers exceeding 2.25 , there were some interesting differences in importance for each driver in different types of development. Figure 5 presents the eleven drivers with the biggest score changes between small change, typical full-scale, and radical development (Kruskal-Wallis, $\mathrm{N}=141, \mathrm{P}<0.1$ ).

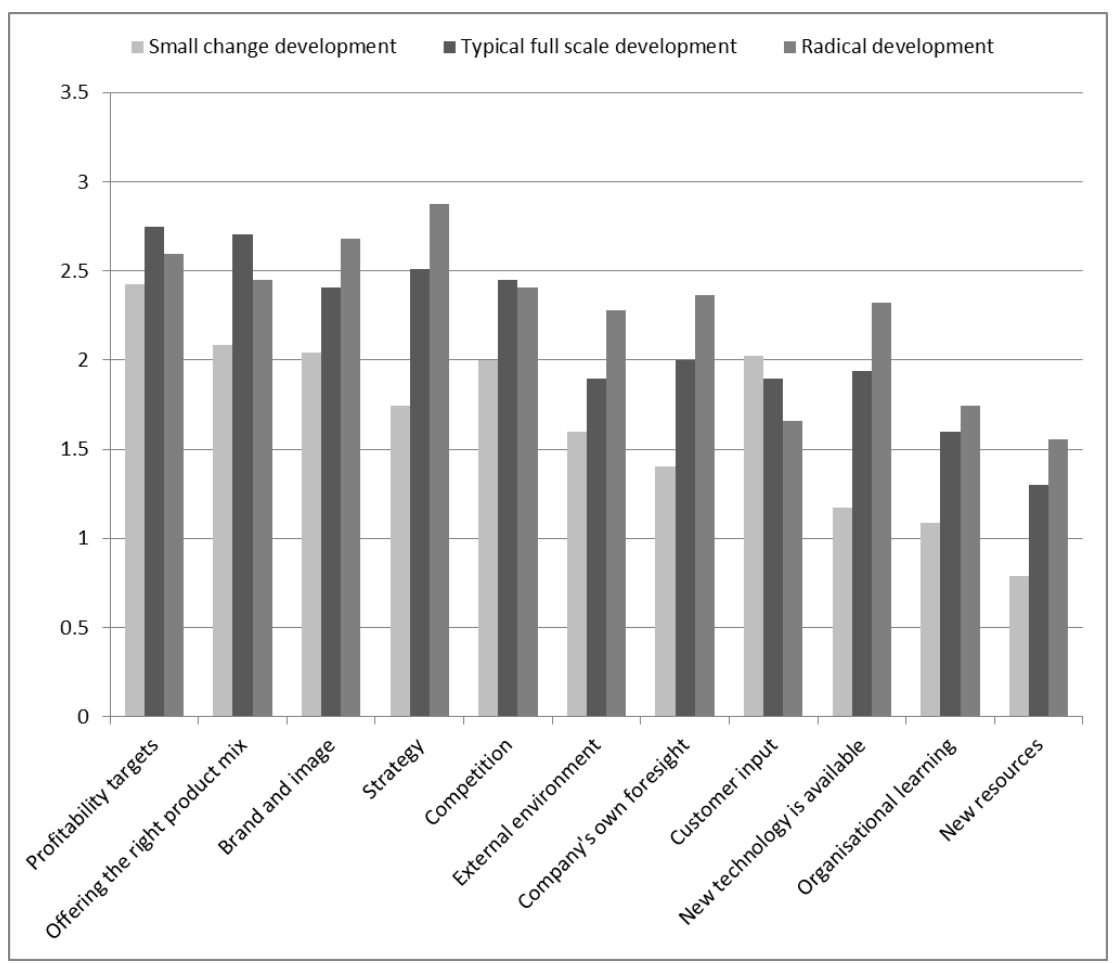

Figure 5. Drivers with biggest changes in importance between project types

The importance of many drivers increased in the case companies in typical full-scale and radical development compared to small change development. These drivers with increasing importance include strategy $(\mathrm{P}<0.001)$, new technology $(\mathrm{P}<0.001)$, company's own foresight $(\mathrm{P}<0.001)$, external environment $(\mathrm{P}<0.001)$, new resources $(\mathrm{P}<0.001)$, brand and image $(\mathrm{P}<0.001)$, and organisational learning $(\mathrm{P}<0.001)$. Strategy became the fourth most important driver in typical full-scale development and the most important one in radical development with a score of 2.87. The respondents were almost unanimous in their opinion: only one respondent saw strategy as just somewhat important in radical development.

The availability of new technology had the highest increase in score between small change and radical development: from 1.17 to 2.32 . However, new technology was only the eighth most important driver in radical development. Company's own foresight also had a very high increase in importance in typical full-scale and radical development. The increase in importance 


\section{Author}

between small change and radical development was lower, yet significant, in external environment, company brand and image, organisational learning, and new resources.

The project type had an interesting effect on offering the right product mix $(\mathrm{P}=0.001)$ and profitability targets $(\mathrm{P}=0.031)$. They were considered more important in typical full-scale development than in small change and radical development. Offering the right product mix was the second most important driver in typical full-scale development (score 2.70) after profitability targets $(2.74)$. Competition $(\mathrm{P}=0.005)$ was also found to have higher importance in typical full-scale development compared to small change and, to some extent, radical development.

In contrast to the typical trend of increasing importance, there were also drivers that the respondents considered less important in typical full-scale and radical development than in small change development. Customer input $(\mathrm{P}=0.061)$ was considered important in small change development (score 2.02). In typical full-scale development its score was 1.89 , and in radical development only 1.66. Besides customer input, only production process had higher importance in small change development compared to typical full-scale and radical development, yet the difference was not statistically significant.

\subsection{Differences between companies}

In addition to the project types, the case companies were also analysed individually. Figure 6 below presents the five drivers with the biggest differences between highest and lowest scores.

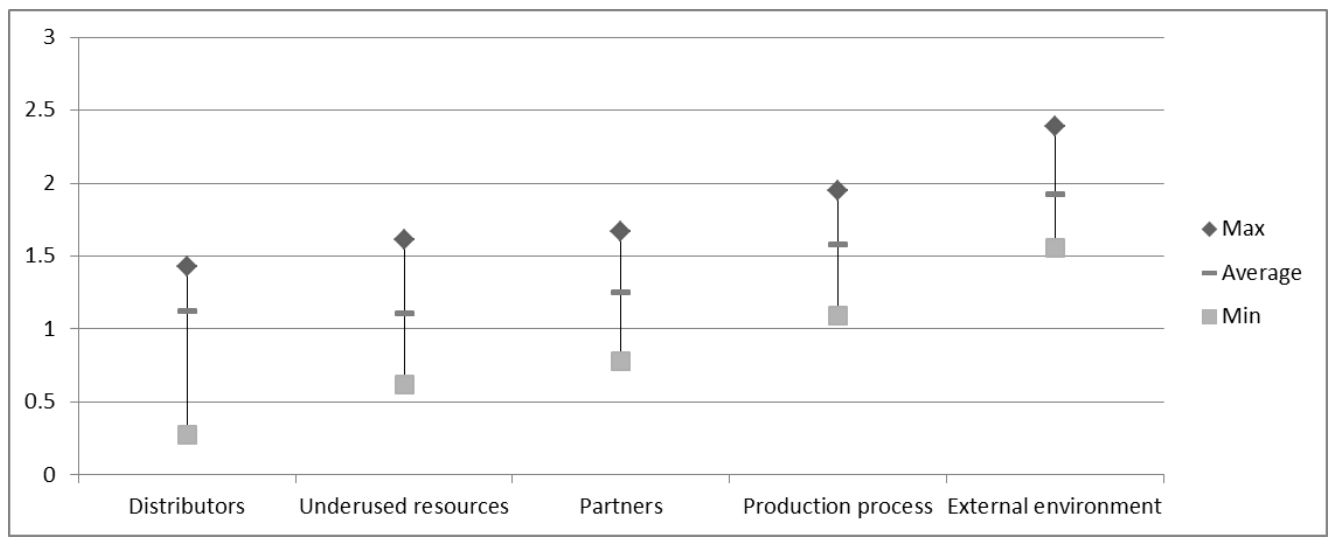

Figure 6. Drivers with biggest differences in scores given by the case companies

The biggest differences in opinions among companies were found in distributors (KruskalWallis, $\mathrm{N}=141, \mathrm{P}<0.001)$, underused resources $(\mathrm{P}<0.001)$, external environment $(\mathrm{P}=0.004)$, partners $(\mathrm{P}=0.005)$, and production process $(\mathrm{P}=0.063)$. Company $\mathrm{A}$, which gave the highest score for distributors, has a channel structure where the distributors play a key role. Similarly, Company D, which gave the lowest score, sells products directly to customers without distributors. The amount of underused resources also differs among companies, resulting in significant differences in given scores. Company B saw underused resources as an important driver in typical full-scale and radical development, whereas most other companies saw it as just somewhat important. The role of partners in product development differs among companies. Partners are an important product development driver for Company B, whereas for 
Title

others, especially for $\mathrm{D}$, development is more internally driven. Production process was considered between important, in Company B, and somewhat important, in Company E. Finally, the importance of external environment was very high for Company B, which operates in an environment with rapid changes in consumer fashion. Companies $\mathrm{E}$ and $\mathrm{G}$, which gave the lowest scores, saw the role of external environment as less important.

On the other hand, the smallest differences in opinions among the case companies were found in profitability targets that were considered very important by all companies. The highest company score for it was 2.89 and the lowest 2.5 .

The results of $\mathrm{B} 2 \mathrm{~B}$ and $\mathrm{B} 2 \mathrm{C}$ company respondents were also compared, and they were found surprisingly similar (see Appendix for details). However, for small change development, B2C companies considered competition (Kruskal-Wallis, $\mathrm{N}=47, \mathrm{P}=0.039$ ), company brand and image $(\mathrm{P}=0.040)$, suppliers $(\mathrm{P}=0.040)$, and new technology $(\mathrm{P}=0.093)$ more important than $\mathrm{B} 2 \mathrm{~B}$ companies. On the other hand, $\mathrm{B} 2 \mathrm{~B}$ companies saw customer input $(\mathrm{P}=0.068)$ as more important than B2C companies. In typical full-scale and radical development, differences proved even smaller. In typical full-scale development, statistically significant differences were not found. Company brand and image was somewhat more important for B2C than for B2B respondents. Competition and external environment were slightly more important for $\mathrm{B} 2 \mathrm{~B}$ than for B2C companies. In radical development, the only statistically significant difference was found in new resources $(\mathrm{P}=0.035)$, which was considered more important by $\mathrm{B} 2 \mathrm{C}$ than $\mathrm{B} 2 \mathrm{~B}$ respondents. B2B companies saw new technology and production process as somewhat more important than $\mathrm{B} 2 \mathrm{C}$ companies. $\mathrm{B} 2 \mathrm{C}$ companies considered partners, and underused resources slightly more important than B2B companies.

Additionally, differences existed in individual opinions inside case companies. Some of these differences in individual opinions could be explained by the role and position of the respondents. Statistically significant differences were found in new resources (Kruskal-Wallis, $\mathrm{N}=141, \mathrm{P}=0.026)$ and company's own foresight $(\mathrm{P}=0.043)$, which both were considered more important by vice presidents and senior managers / heads compared to directors and programme / project managers. The rest of the differences proved statistically insignificant. However, vice presidents seemed to stress customer input and partners. Directors, on the other hand, emphasised company brand and image, and programme and project managers perceived suppliers more important than other respondents on average. Regarding functions, operations and logistics and product development respondents stressed the importance of the production process. Finally, marketing respondents emphasised the importance of company brand and image and customer input.

\section{Discussion}

This study indicated six key product development drivers: profitability targets, revenue targets, offering the right product mix, company brand and image, strategy, and competition. These six key drivers were considered clearly more important than the other twelve (Figure 2). In addition, the results showed the key drivers for different project types (Figure 4). This study also indicated that despite the fact that customer input was seen as important in small change and typical full-scale development, it was only the fifth most important driver in small change development and the ninth most important one in typical full-scale development. Finally, the importance of drivers differed significantly among the case companies, but the opinion differences among the respondents of B2B and B2C companies proved surprisingly small. 
Author

\subsection{Theoretical implications}

Literature discusses the importance of innovation and product development and represents different types of product development drivers (e.g. Acur, Kandemir, and Boer, 2012; Ansoff, 1957; Cooper, 2011; Hassanien and Dale, 2012; Kahn, 2001; Nidumolu, Prahalad, and Rangaswami, 2009; Trott, 2002; Veryzer, 1998). Most authors (e.g. Cooper, 2011) focus on a high-level view, whereas others such as Veryzer (1998) and Kinkel and Som (2010) have focused on specific aspects of product development drivers.

The literature review and cases analysed in this study indicated three important driver groups: financial goals, marketing and customers, and strategy and business environment. The importance of strategy has been emphasised in the literature (e.g. Acur, Kandemir, and Boer, 2012; Ansoff, 1957), but in this study financial goals and marketing and customers were seen as more important than strategy. In addition, technology proved to be only somewhat important, which may be due to the case companies being established ones, not start-ups.

The literature synthesis and survey results indicated many important drivers for product development, and therefore common technology-push vs. market-pull classification (Hart et al., 2003; Rothwell, 1992) can be considered as a simplification. In addition, this study provides new knowledge by clarifying the most important drivers for small change, typical full-scale, and radical development. This study complements past research by synthesising a list of main product development drivers. The research is in line with Veryzer (1998) by finding that key drivers for radical and small change development differ significantly.

\subsection{Managerial implications}

There are many drivers that initiate product development projects in companies. The results of this study indicate that opinions on product development drivers differ significantly among project types and companies, and individual opinions may vary. Properly aligned product development drivers can improve decision-making and project outcomes. Therefore, companies should systematically and intentionally clarify their product development drivers for different types of projects and situations.

The results of this study indicate significant differences in driver importance for different project types. For small change development, the number of very important drivers was only two; for typical full-scale development six, and for radical development the number was nine. Despite customer input being generally considered beneficial and many companies claiming to be customer-oriented, this study gave direct customer input relatively low priority. The results indicated that direct customer input was important for small change and typical full-scale development, but only somewhat important for radical development. This may be due to difficulty in gathering customers' long-term needs and requirements. On the other hand, for radical development there were many very important drivers including strategy, company brand and image, and company's own foresight.

The results for B2B and B2C companies were surprisingly similar. However, product development drivers were perceived differently by individual companies, and managers ought to understand that the drivers are company-specific. The drivers which were seen least consistently included distributors, underused resources, external environment, partners, and production process. The differences in opinions probably result from different business, distribution, and operation models, and the business environments that the companies face.

This study indicated that there were differences individual opinions inside the case companies. The companies should spend time clarifying their key drivers and ensure that the 
Title

opinions are aligned. It is very important for individuals to understand the big picture, which cannot be achieved without internal discussion. A mutual understanding of priorities enables a company to successfully implement its product strategy.

\section{Conclusions}

Product development is critical in today's business. Products are becoming increasingly complex, and many projects are carried out in development networks in different geographical locations. In addition, the needs of customers and internal and external stakeholders must be addressed. As a result, managing product development has become challenging. Clarification of product development drivers can be considered as one way to reduce unnecessary complexities and improve decision-making in companies. This paper presents a synthesising list of main product development drivers based on literature, and studies how these drivers are valued at the managerial level in NPD-intensive companies.

The results of the literature review and the empirical study among industrial managers indicate eighteen significant product development drivers, the most important ones being profitability targets, revenue targets, offering the right product mix, company brand and image, strategy, and competition. When considering product development drivers, industrial managers should not think that the most important drivers are the same in all cases. The differences between individual companies proved significant. In addition, the study revealed substantial differences in drivers for small change, typical full-scale, and radical development. It would be beneficial for companies to clarify their own drivers and form a shared understanding, in order to improve decision-making and reduce unnecessary ambiguities.

The limitations of this study include the limited number of surveyed companies, the focus on a single country, and the overall sample size being relatively small. Also, the characteristics of studied companies differed in many ways, making statistically reliable comparisons difficult. Recommended future study, besides addressing these limitations, could include how well the findings of this study apply to different types of companies, such as service sector and subcontractors.

\section{Acknowledgements}

The authors would like to thank Osmo Kauppila, Jyrki Hietaniemi, Juha Ala-Mursula, and the survey respondents in the case companies for their valuable inputs.

\section{References}

Acur, N., Kandemir, D. and Boer, H. (2012) 'Strategic alignment and new product development: Drivers and performance effects', Journal of Product Innovation Management, Vol. 29, No. 2, pp. 304-318.

Ansoff, H.I. (1957) 'Strategies for Diversification', Harvard Business Review, Vol. 35, SeptemberOctober, pp. 113-124.

Berggren, E. and Nacher, T. (2001), 'Introducing new products can be hazardous to your company: Use the right new-solutions delivery tools', Academy of Management Executive, Vol. 15, No. 3, pp. 92101 . 


\section{Author}

Booz, Allen and Hamilton (1982) New Product Management for the 1980s, Booz, Allen and Hamilton, New York.

Bossink, B.A.G. (2004), 'Managing drivers of innovation in construction networks', Journal of Construction Engineering and Management, Vol. 130, No. 3, pp. 337-345.

Boulding, W., Morgan, R. and Staelin, R. (1997), 'Pulling the plug to stop the new product drain', Journal of Marketing Research, Vol. 34, No. 1, pp. 164-176.

Bralla, J.G. (1996) Design for Excellence, 1st ed., McGraw-Hill, New York, NY.

Chesbrough, H.W. (2003) Open innovation: the new imperative for creating and profiting from technology, Harvard Business School Publishing Corporation, USA.

Cooper, R.G. (2004) Product leadership, 2nd ed., Basic Books, New York.

Cooper, R.G. (2011) Winning at New Products: Creating Value Through Innovation, 4th ed., Basic Books, USA.

van Echtelt F.E.A., Wynstra, F., van Weele, A.J. and Duysters, G. (2008) 'Managing Supplier Involvement in New Product Development: A Multiple-Case Study', Journal of Product Innovation Management, Volume 25, Issue 2, pp. 180-201.

Ettlie, J. (2006) Managing innovation: new technology, new products, and new services in a global economy, 2nd ed., Elsevier Butterworth-Heinemann, USA.

Hamel, G. and Prahalad, C.K. (1994) 'Competing for the Future', Harvard Business Review, Vol. 72, No. 4 (Jul/Aug), pp. 122-128.

Hamm, S. (2006) 'Speed Demons', BusinessWeek, March 27th, pp. 69-76.

Hart, S., Hultink, E.J., Tzokas, N. and Commandeur, H.R. (2003), 'Industrial companies' evaluation criteria in new product development gates', Journal of Product Innovation Management, Vol. 20, No. 1, pp. 22-36.

Hassanien, A. and Dale, C. (2012) 'Drivers and barriers of new product development and innovation in event venues: A multiple case study', Journal of Facilities Management, Vol. 10, No. 1, pp. 75-92.

Isoherranen, V. and Kess, P. (2011) 'Strategy Orientation Analysis in the Mobile Phone Case Business', Modern Economy, Vol. 2, pp. 395-402.

Kahn, K.B. (2001) Product planning essentials, Sage Publications, USA.

Kinkel, S. and Som, O. (2010) 'Internal and external R\&D collaboration as drivers of the product innovativeness of the German mechanical engineering industry', International Journal of Product Development, Vol. 12, No. 1, pp. 6-20.

Kotler, P. and Keller, K.L. (2009) Marketing management, 13th ed., Pearson Prentice Hall, USA.

Krishnan, V. and Ulrich, K. (2001) 'Product development decisions: a review of the literature', Management Science, Vol. 47, No. 1 (January), pp. 1-21.

Krishnan, V., Eppinger, S.D. and Whitney, D.E. (1997) 'A model-based framework to overlap product development activities’, Management Science, Vol. 43, No. 4, pp. 437-451.

Lakemond, N., Lovén, E. and Detterfelt, J. (2010) 'Understanding creativity motors and obstacles in product development', International Journal of Product Development, Vol. 11, No. 3-4, pp. 272-288.

Lantos, G.P., Brady, D.L. and Mccaskey, P.H. (2009) 'New product development: An overlooked but critical course', Journal of Product and Brand Management, Vol. 18, No. 6, pp. 425-436.

Mottonen, M., Harkonen, J., Belt, P., Haapasalo, H. and Simila, J. (2009) 'Managerial view on design for manufacturing', Industrial Management and Data Systems, Vol. 109, No. 6, pp. 859-872.

Myers, S. and Marquis, D.G. (1969) Successful industrial innovation: a study of factors underlying innovation in selected firms, National Science Foundation, Washington.

Narver, J.C. and Slater, S.F. (1990) 'The effect of a market orientation on business profitability', Journal of Marketing, Vol. 54, October, pp. 20-35.

Nidumolu, R., Prahalad, C.K. and Rangaswami, M.R.( 2009) 'Why sustainability is now the key driver of innovation', Harvard Business Review, Vol. 87, No. 9, pp. 57-64. 
Title

Pavitt, K. (1990) 'What we know about the strategic management of technology', California Management Review, Vol. 32, No. 3, pp. 17-26.

Prahalad, C.K. and Hamel, G. (1990) 'The core competence of the corporation', Harvard Business Review, Vol. 68, No. 3, pp. 79-81.

Rothwell, R. (1992) 'Successful industrial innovation: critical factors for the 1990s', $R \& D$ Management, Vol. 22, No. 3, pp. 221-240.

Schilling, M.A. and Hill, C.W.L. (1998) 'Managing the new product development process: Strategic imperatives', IEEE Engineering Management Review, Vol. 26, No. 4, pp. 55-68.

Song, X.M. and Montoya-Weiss, M.M. (1998) 'Critical development activities for really new versus incremental products', Journal of Product Innovation Management, Vol. 15, No. 2, pp. 124-135.

Sull, D.N. (1999) 'Why Good Companies Go Bad', Harvard Business Review, Vol. 77, No. 4, pp. 42-48, $50-52,183$.

Trott, P. (2002) Innovation Management and New Product Development, Pearson Education Limited, Harlow, UK.

Ulrich, K. and Eppinger, S.D. (2000) Product Design and Development, 2nd ed., McGraw Hill, Singapore.

Schumpeter, J.A. (1939) Business Cycles, McGraw-Hill, New York.

Veryzer Jr., R.W. 1998 'Discontinuous Innovation and the New Product Development Process', Journal of Product Innovation Management, Vol. 15, No. 4, pp. 304-321. 
Author

\section{Appendix}

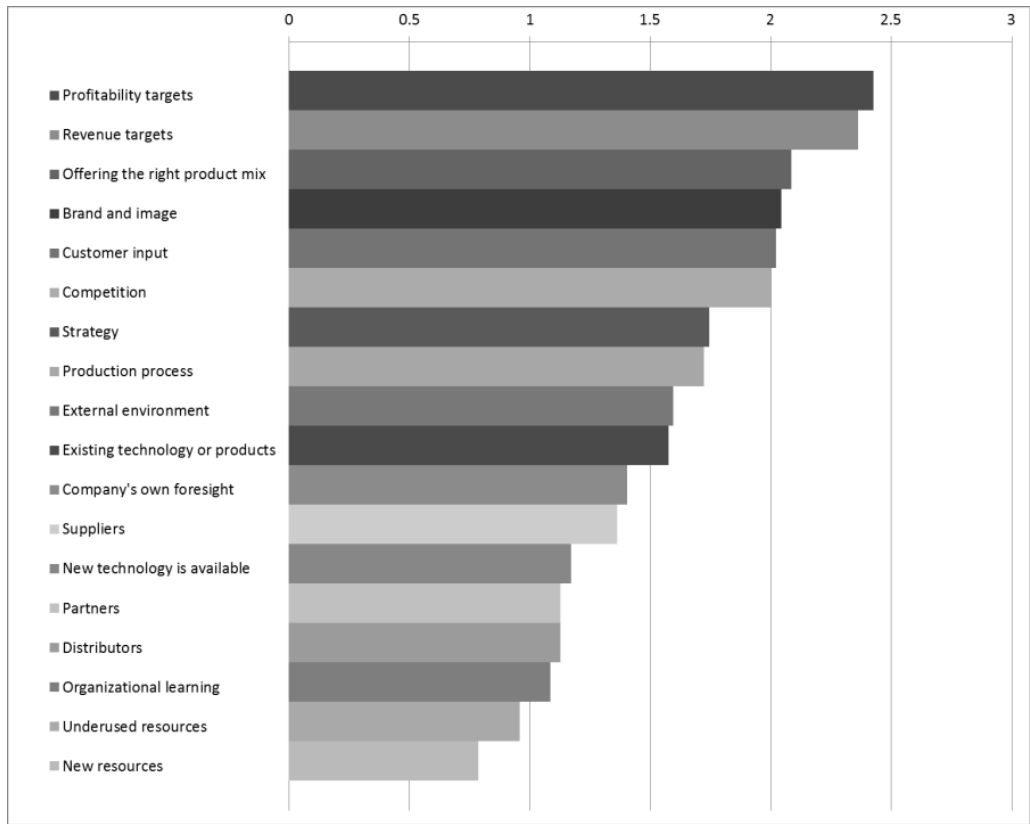

Figure 7. Drivers for small change development

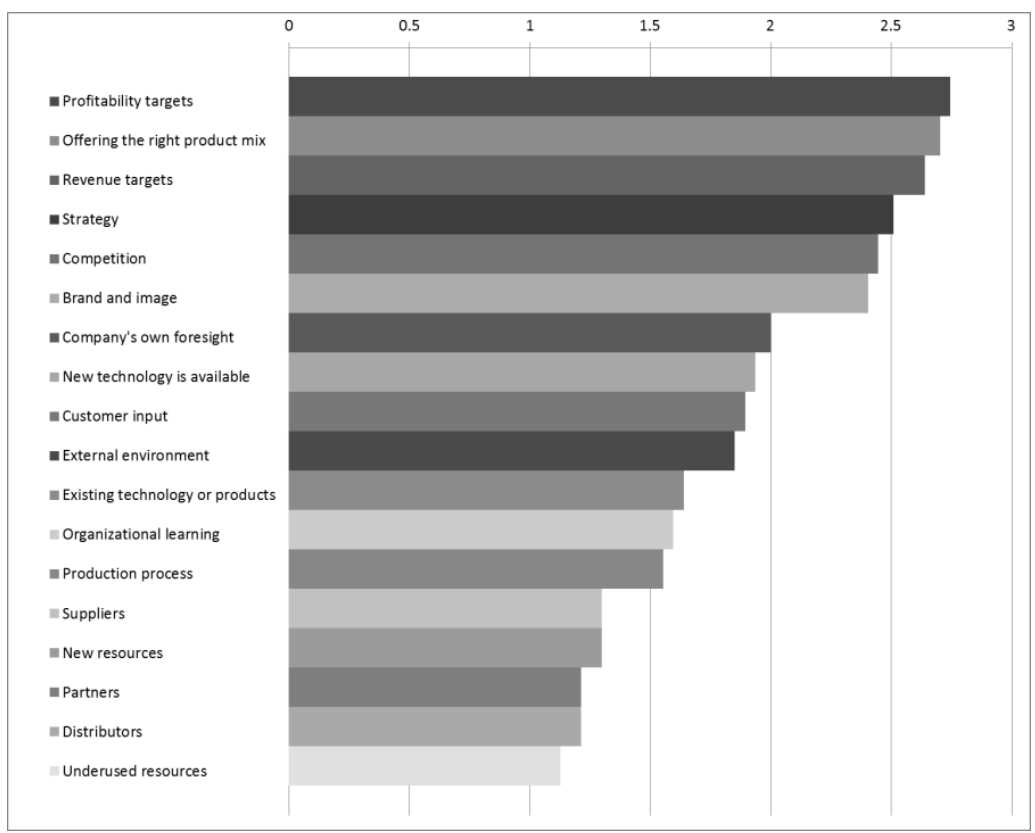

Figure 8. Drivers for typical full-scale development 
Title

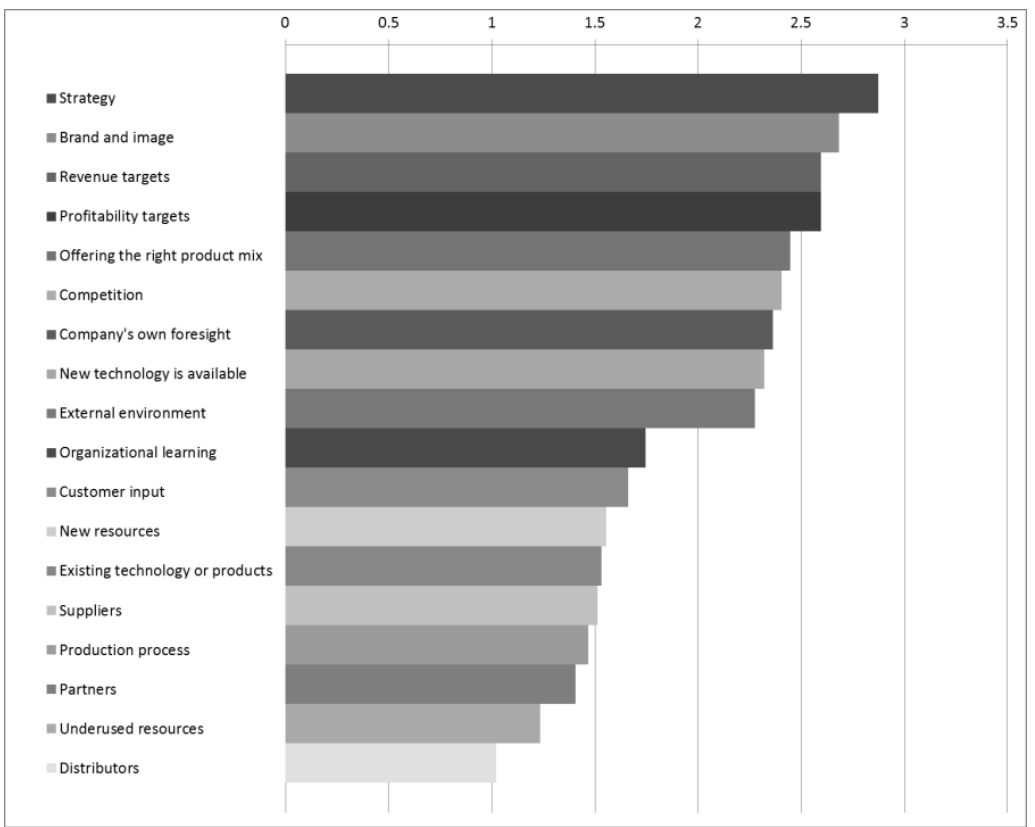

Figure 9. Drivers for radical development

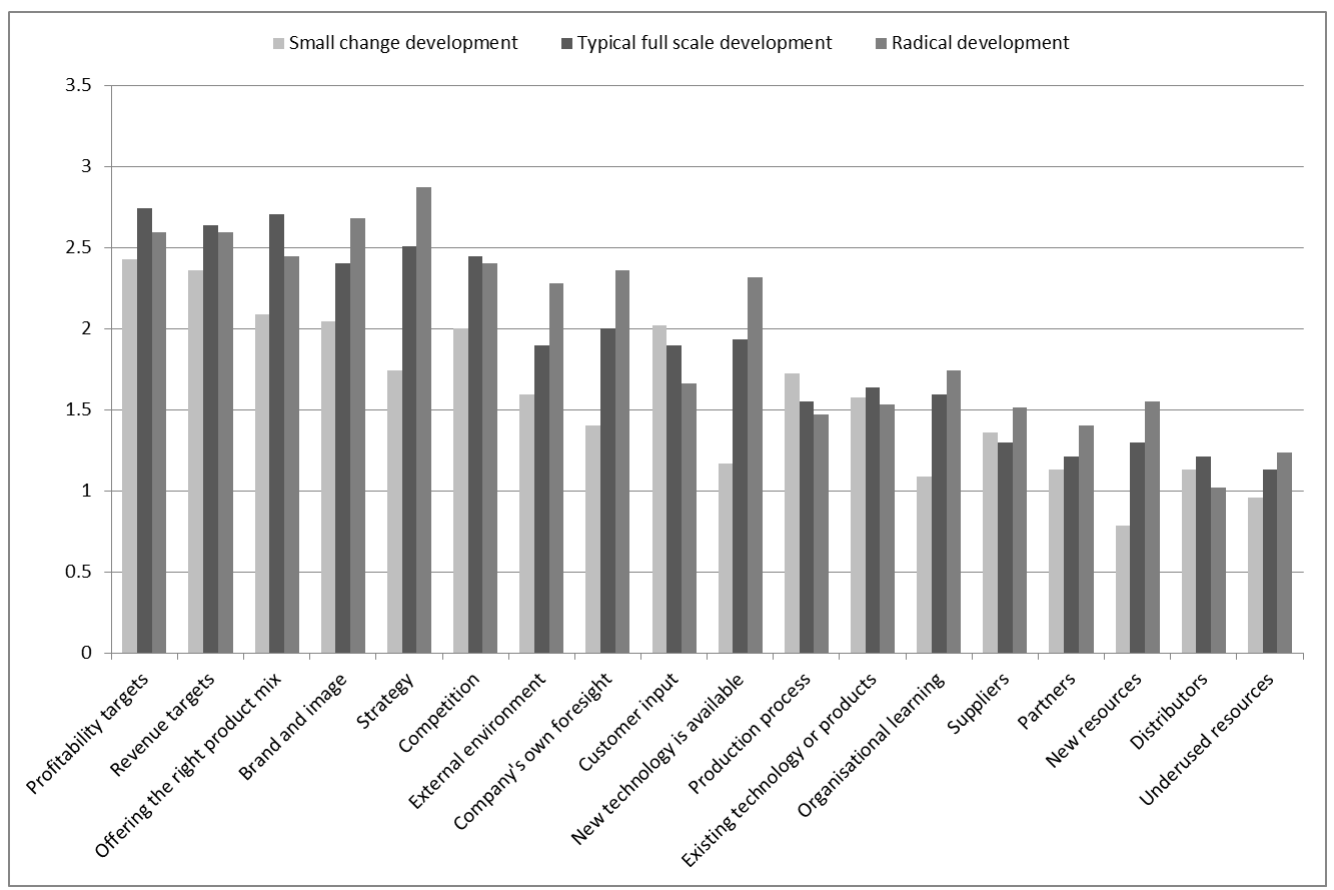

Figure 10. Driver importance changes between project types 


\section{Author}

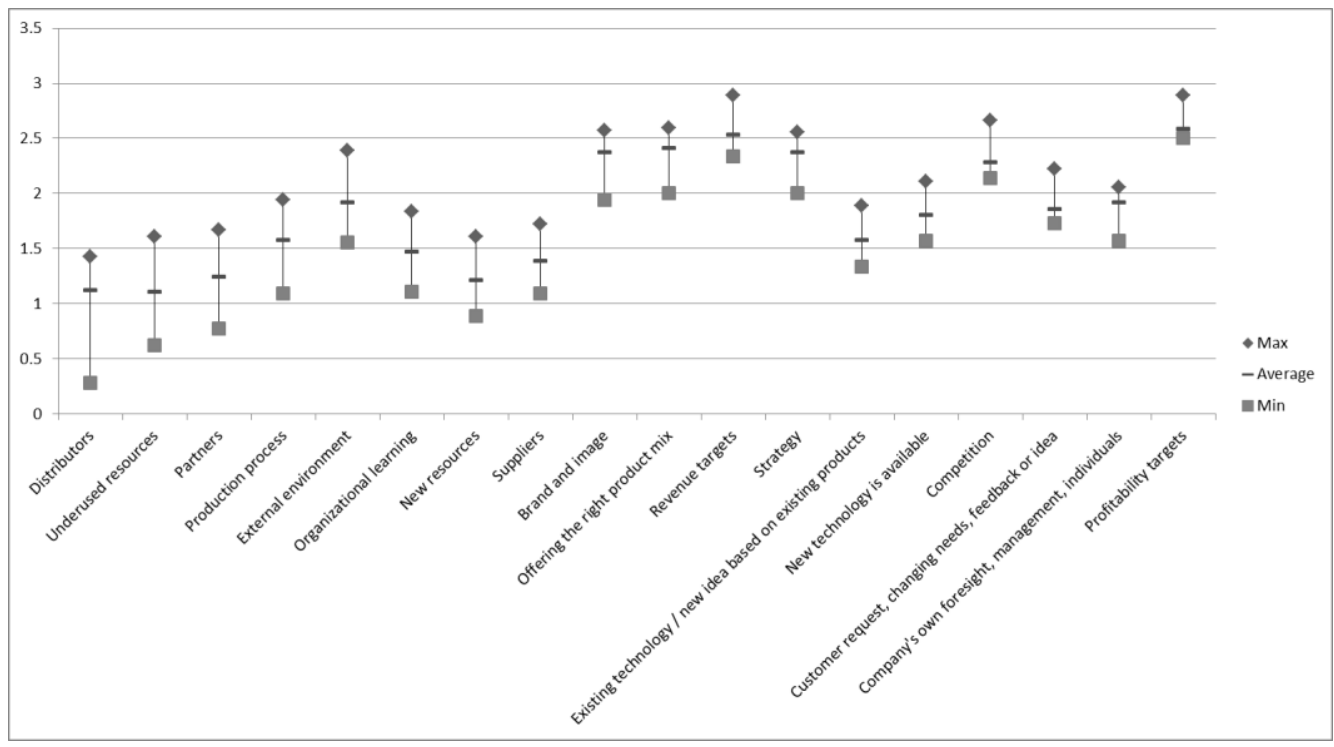

Figure 11. Differences in driver scores given by the case companies

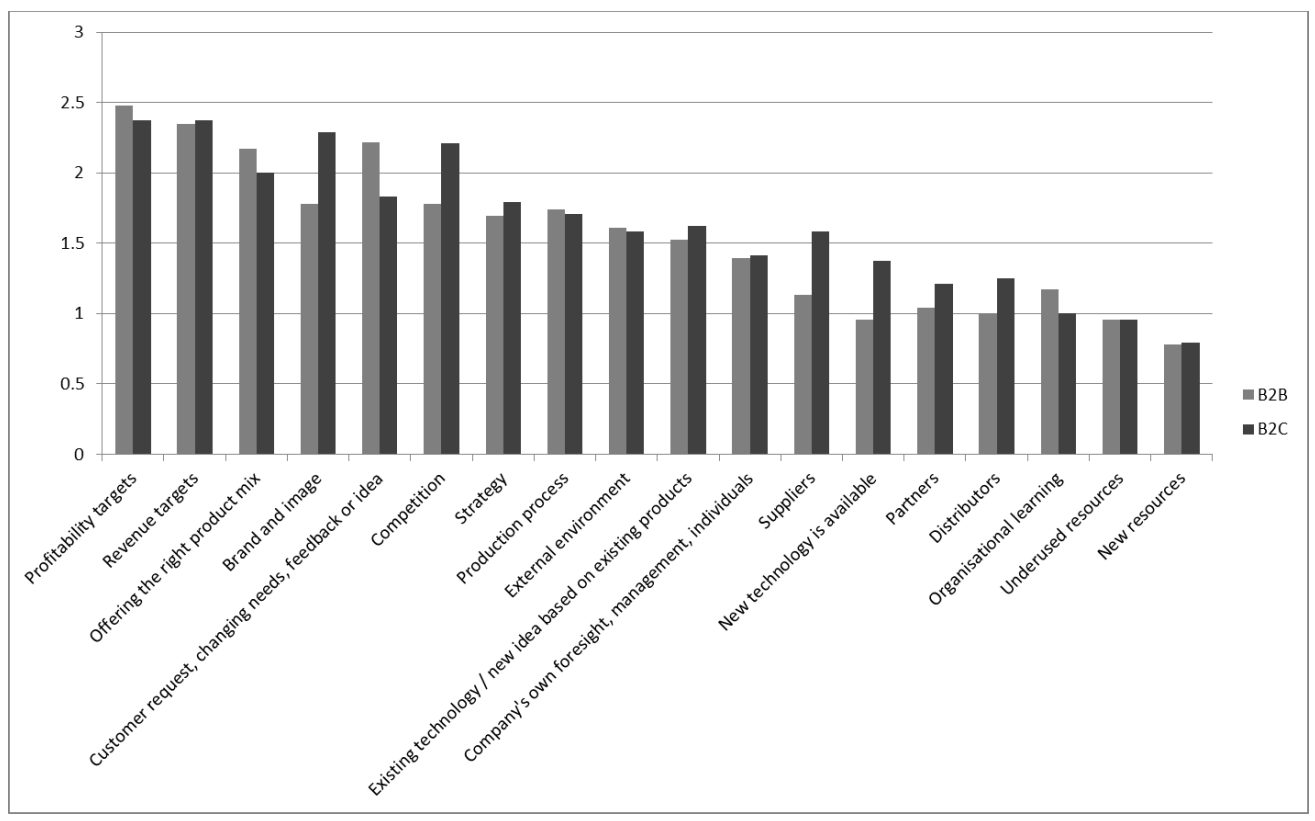

Figure 12. B2B vs. B2C respondents' view on drivers for small change development 


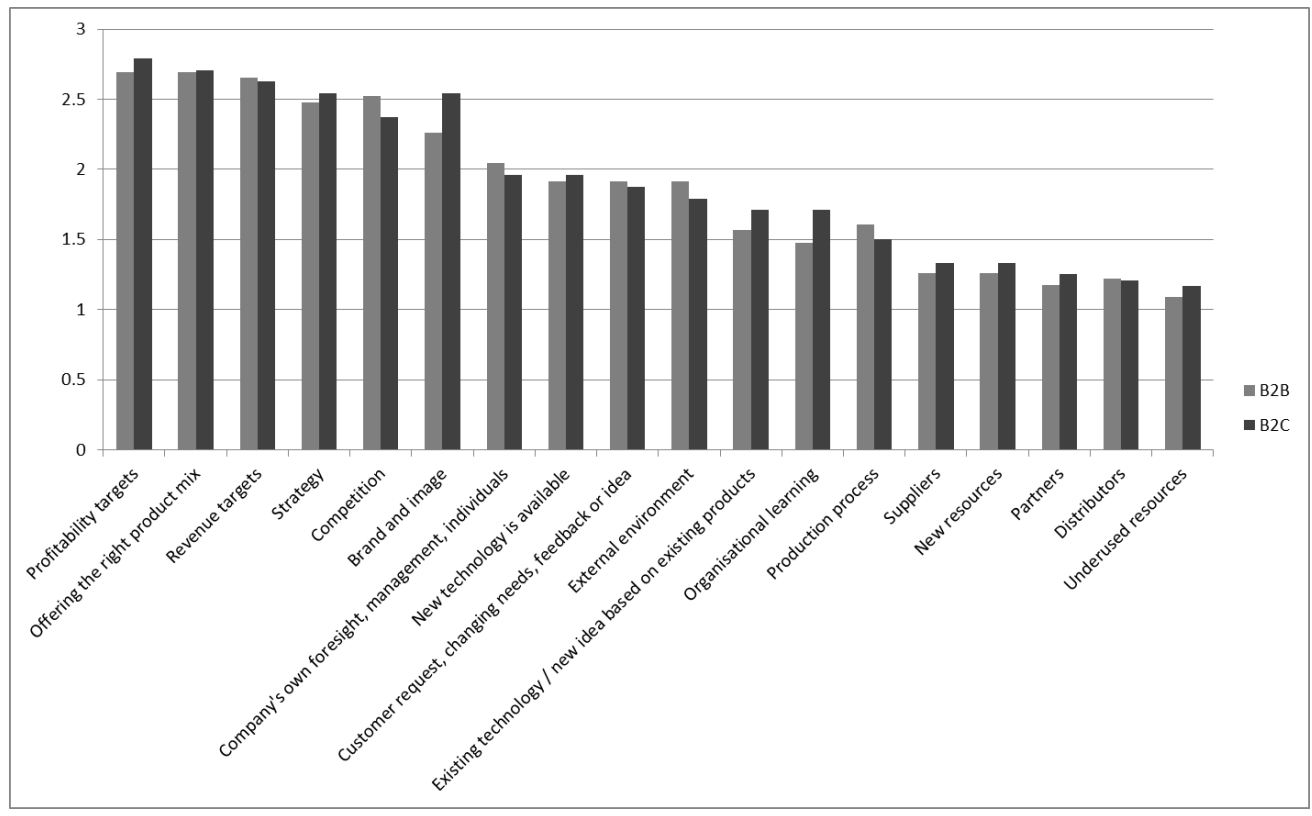

Figure 13. B2B vs. B2C respondents' view on drivers for typical full-scale development

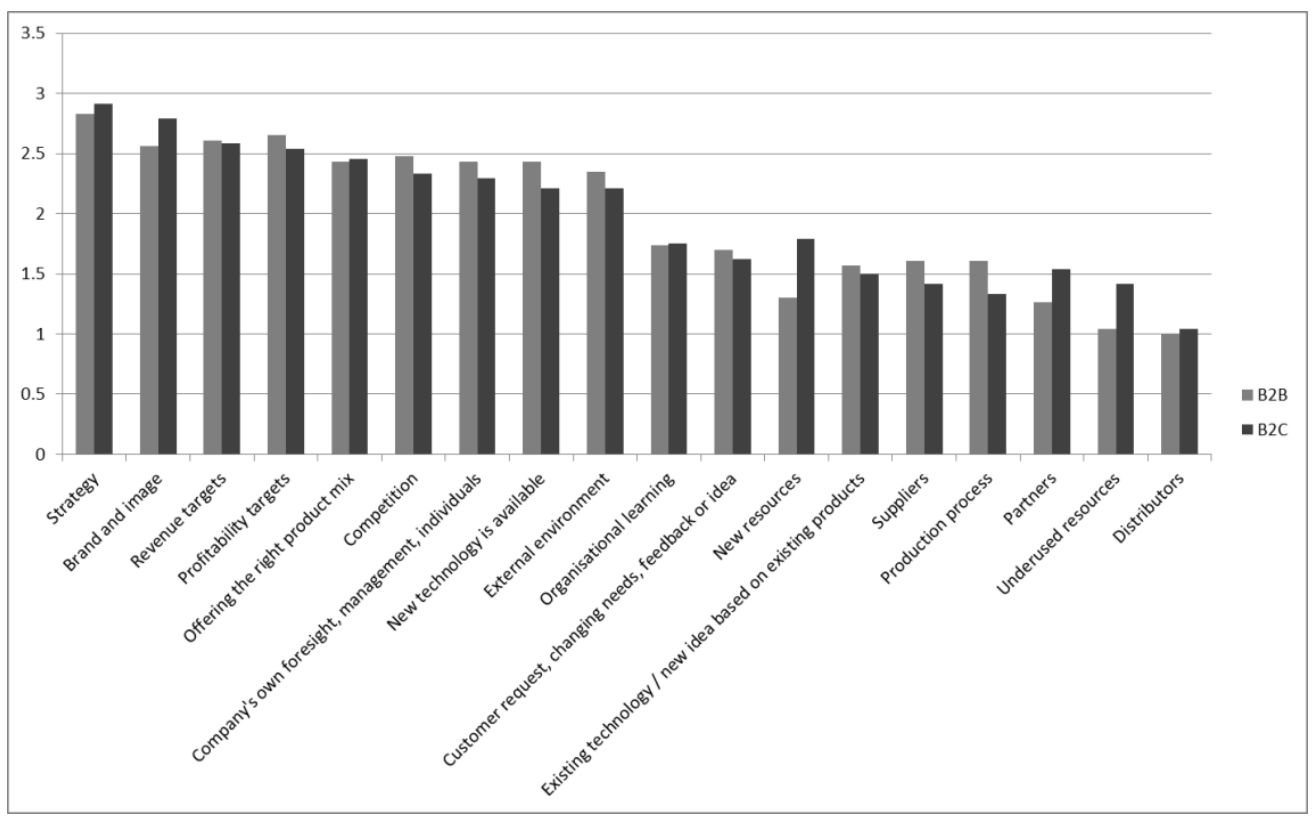

Figure 14. B2B vs. B2C respondents' view on drivers for radical development 